\title{
REALIZING SELF-REALIZATION: CORPORATE POLITICAL EXPENDITURES AND REDISH'S THE VALUE OF FREE SPEECH
}

\section{EDWin BAKer $†$}

In First National Bank v. Bellotti, 1 the Supreme Court invalidated a Massachusetts statute prohibiting most corporate contributions and expenditures made to influence voting on referendum and initiative proposals. The Court reasoned that "[w]e . . . find no support in the First or Fourteenth Amendment ... for the proposition that speech that otherwise would be within the protection of the First Amendment loses that protection simply because its source is a corporation." 2 This Supreme Court decision to protect profit-oriented corporate political speech will, if followed, probably do more to undermine people's "ability to control [their] own destiny" 3 than any of the Court's recent refusals to protect self-expressive conduct. ${ }^{4}$ This consequence, taken along with Professor Redish's apparent approval of the decision, ${ }^{5}$ makes Bellotti a particularly good lens through which to begin to examine Redish's development of the self-realization value that he asserts is basic to the first amendment.

$\uparrow$ Professor of Law, University of Oregon. Visiting Professor of Law, University of Pennsylvania. B.A. 1969, Stanford University; J.D. 1972, Yale University.

1435 U.S. 765 (1978).

2 Id. 784.

3 The ability to control one's own destiny is one of two components of the fundamental value of self-realization that Redish finds at the base of the first amendment. Redish, The Value of Free Speech, 130 U. PA. L. Rev. 591, 593 (1982).

4 Although from a doctrinal perspective other decisions may be greater catastrophies, see, e.g., Krattenmaker and Powe, Televised Violence: First Amendment Principles and Social Science Theory, 64 VA. L. Rev. 1123 (1978) (criticizing FCC v. Pacifica Found., 438 U.S. 726 (1978)), the conclusion that Bellotti "most" undermines self-determination reflects guesses about the practical effects of the decision. See, e.g., Miller, On Politics, Democracy, and the First Amendment: A Comment on First National Bank v. Bellotti, 38 WASF. \& LEE L. Rev. 21 (1981). Early studies clearly recognized the importance of regulation of corporate political speech to political freedom. One commentator, for example, observed that:

The dependence of both major parties upon the contributions of substantial business interests puts them at the mercy of this group when it comes to the formulation of policies. . . . It is quite possible that the people have no desire to be "free" but they ought to be given at least an even chance for freedom if they wish it.

L. Overacker, Money IN Elemctions 197 (1932).

5 Cf. Redish, supra note 3, at 630-35 (discussion of commercial speech). 


\section{Corporate Political Expenditures}

Corporate resources are sufficient to dominate the financing of electoral as well as initiative and referendum campaigns. With the cost of a presidential campaign being in the millions of dollars, the potential purchasing power available to corporations that control and spend billions is awesome. ${ }^{6}$ Even if frequently evaded, legal restraints may limit the degree to which corporations become involved in the financing of electoral campaigns. ${ }^{7}$ Since Bellotti freed the corporation of these restraints in ballot-measure campaigns, corporate contributions have frequently dominated the financing of campaigns related to corporate interests. ${ }^{8}$ For example,

6 In the 1980 presidential election, the most costly in our history, all major party candidates together spent about $\$ 100$ million in the primaries, and more than $\$ 130$ million in government and private funds was spent in the general election. Bonafede, A $\$ 130$ Million Spending Tab Is Proof-Presidential Politics Is Big Business, 13 Nat'l J. 50 (1981); see also 1980 Fed. Elegtton Commission AnN. REP. 16-17.

The magnitude of corporate power can be seen if one compares the half-billion dollars spent on all campaigns in 1972, a presidential election year, with business's approximately $\$ 60$ billion yearly budget for advertising and sales promotion during the late 1960's. C. LindBlom, Politics and Markers 195, 214 (1977). A significant portion of the half-billion spent on elections came from corporate sources. See id.

7 See infra note 11.

8 Montana's amicus brief in Bellotti reported that corporate sources had contributed approximately $\$ 144,000$ in opposition to a ballot measure related to the nuclear power industry, compared to $\$ 451$ collected by supporters of the measure. Bellotti, 435 U.S. at 811 n.11 (White, J., dissenting).

In a similar 1976 Colorado initiative campaign, opponents of the measure out-spent proponents four-to-one, with corporate contributions of $\$ 500$ or more accounting for over two-thirds of the opponents' financing. Mastro, Costlow \& Sanchez, Taking the Initiative: Corporate Control of the Referendum Process Through Media Spending and What to Do About It, 32 FED. CoM. L.J. 315, 321 (1980). On this issue, a Denver Post poll in late September indicated that 55\% of respondents were in favor, $26 \%$ were opposed, and $19 \%$ were undecided, but the high spending of the opposition overcame this initial support; the actual voting showed $29 \%$ in favor and $71 \%$ opposed. Id. 360 .

In the same Colorado election, opponents of a ballot measure promoting beverage container recycling raised $\$ 587,842,91 \%$ of which came from corporate contributions of more than $\$ 500$, outspending those favoring the measure 57-to-1. Id. 321,360 . Supporters lost nearly half of their early support, and the opponents more than doubled their support during the campaign. Id. 360 . In a third Colorado initiative campaign that year, opponents of a utility regulation reform measure were financed primarily by utility companies; they raised over a quarter of a million dollars, outspending supporters 45-to-1. Id. 322-23. The voters shifted from an early $55 \%$ to $19 \%$ approval (with $26 \%$ undecided) to $30 \%$ in favor and $70 \%$ opposed on election day. Id. 360 .

The tobacco industry contributed $88 \%$ of the $\$ 960,000$ spent in defeating a 1979 "nonsmokers' rights" initiative in Dade County, Florida. The principal group supporting the measure, which lost by 800 votes out of nearly 200,000 cast, spent $\$ 10,000$ and received $\$ 26,000$ in in-kind contributions. Lydenberg \& Young, Business Bankrolls for Local Ballots, 33 Bus. \& Soc'x Rev. 51, 53-54 (1980). For other examples, see $i d$. 54-55. In a 1980 Maine initiative campaign that would have shut down the nuclear power industry in the state, opponents-primarily 
in a 1979 public power referendum in Westchester County, New York, the Consolidated Edison Company of New York contributed $\$ 1,200,000$ to defeat the proposal, as compared with the $\$ 16,000$ spent by a citizens group that provided the only organized support for the measure. Consolidated Edison's campaign overcame the reported two-to-one initial public support for the measure; the ballot measure received only forty-five percent of the vote on election day. ${ }^{9}$ Although money cannot guarantee electoral success, money clearly does count heavily. Statistical correlations support the conclusion of most informed observers that money often plays a pivotal role in determining nonincumbents' chances for election. ${ }^{10}$

In the early twentieth century, many people concluded that corporate political expenditures did not reflect individuals' political values or party loyalty, but rather were often made solely for an improper purpose, obtaining political favor. These people feared that such corporate expenditures would distort or corrupt democratic decisionmaking. This fear led to a popular reaction that culminated in state and federal legislation prohibiting corporate electoral expenditures. ${ }^{11}$ Passage of these laws was thus the

financed by companies involved in the nuclear power industry-spent nearly $\$ 800,000$, compared to about $\$ 163,000$ raised by supporters from primarily noncorporate sources. The measure was defeated, receiving $41 \%$ of the vote. N.Y. Times, Sept. $24,1980, \S A$, at 1 , col. 6 ; id., Sept. $21,1980, \S A$, at 28, col. 1 ; Christian Sci. Monitor, Sept. 19, 1980, $\$$ A, at 10 , col. 1 .

Of course, sometimes corporate money loses, although this does not mean that it did not have any effect. In a 1981 Washington State ballot measure affecting the financing of large (including nuclear) power projects, opponents spent over a million dollars raised from 500 contributors. The main group supporting the measure raised only $\$ 163,000$ from 2,300 contributors. The New York Times identified the large contributors: six construction, utility, bank, and stock brokerage companies contributed or loaned $\$ 338,000$ to opponents of the measure, whereas two individuals and one union contributed or loaned $\$ 55,000$ to supporters. N.Y. Times, Oct. 31, 1981, $\$ A$, at 8 , col. 1 . The measure passed, receiving nearly $59 \%$ of the vote. N.Y. Times, Nov. 5, 1981, § B, at 17, col. 5; see generally Citizens Against Rent Control v. City of Berkeley, 102 S. Ct. 434, 443 \& nn.2-5 (1981) (White, J., dissenting) (data concerning ballot-measure-campaign contributions). The majority in Bellotti appeared to be unaware of such examples. See Bellotti, 435 U.S. at 789-90.

9 Lydenberg \& Young, supra note 8, at 53.

10 See G. Jacobson, Money in Congresstonat Elections (1980); see also D. Dunn, Financing Presidentral Campaigns (1972); A. Heard, The Costs of DemocracY (1960); Glantz, Abramowitz \& Burkart, Election Outcomes: Whose Money Matters?, 38 J. Por. 1033 (1976); Welch, The Effectiveness of Expenditures in State Legislative Races, 4 AM. Por. Q. 333 (1976). Jacobson indicates that the main barrier to concluding that these correlations show a causal effect is that the same characteristics that encourage contributions may also attract votes. G. JACOBson, supra, at 49 . But even if these characteristics attract both votes and contributions, it is quite possible that receiving the contributions is a crucial intermediate step in obtaining the votes. See id.

11 See, e.g., United States v. UAW, 352 U.S. 567, 570-75 (1957) (history of restrictions on corporate political contributions). 
product of people's attempts to exercise some control over their destiny, and the object of the laws, moreover, was to create a political process that would better enable people to exercise such control. Yet, in Bellotti, a closely divided Court held that one of these acts of self-government, even if aimed at furthering or purifying the process of self-rule, was an unconstitutional abridgement of first amendment-protected freedom of speech.

Justice White's dissent in Bellotti, in which Justices Brennan and Marshall concurred, carefully demonstrated that the values

Although bans on corporate contributions have never been anything close to totally effective, the federal government's Tillman Act of 1907 and the prohibitions on corporate contributions adopted by more than thirty states in the period 1900 to 1920 apparently lessened the corporate role from the dominance it had achieved after the Pendleton Act of 1883, which restricted the assessment of "contributions" from federal civil servants. See L. Overacker, supra note 4, at 234-36, 294, 303, 337; E. Sikes, State and Federal Corrupt-Practices Legislation 107-08, 127-28, 188-92 (1928); G. Thayer, Who Shakes the Money Tree? 38-41, 53-54 (1973).

During the period of reform, the two most common justifications given for limiting corporate political contributions were that: (1) if the contributions reflected the political views of management, they were improperly forcing the stockholders to subsidize their views, and (2) if intended (as seemed consistently to be the case) solely to promote corporate profits, the contributions would corrupt the political process. In support of the second point, writers repeatedly emphasized that these corporate contributions were "not determined by political sentiments, principles, or party loyalty." E. SKkEs, supra, at 108; see also L. OVERACKER, supra note 4, at 177-88; E. SrRes, supra, at 108-13. This view strongly suggests that the lack of connection between the contributions and people's political sentiments is a key factor in making such expenditures objectionable as corrupting the political process, whereas the presence of such a connection would raise objections to "executive officers ... impos[ing] their political views upon a constituency of divergent convictions." E. SIKEs, supra, at 110 (quoting Testimony Taken Before the Joint Committee of the Senate and Assembly of the State of New York to Investigate and Examine Into the Business and Affairs of Life Insurance Companies Doing Business in the State of New York (Armstrong Committee) 397 (1905)); see also id. 190-91, 247.

Although it was not mentioned in the reform rhetoric justifying the ban on corporate restrictions, one wonders whether some corporate interests quietly supported the legislation as a means to avoid the pressure to contribute created by the fear of political retaliation, see G. ThIAYer, supra, at 46. Cf. Capital Broadcasting Co. v. Mitchell, 333 F. Supp. 582, 587-89 (D.D.C. 1971) (Wright, J., dissenting) (federal prohibition on cigarette advertising on electronic media enabled tobacco industry to avoid conflict between their need to advertise to maintain brand loyalty and their desire to discontinue television and radio advertising in order to avoid the effective anti-smoking messages that under the fairness doctrine resulted from their advertising), aff'd mem. sub nom. Capital Broadcasting Co. v. Acting Att'y Gen., 405 U.S. 1000 (1972). One could also argue, particularly in light of their massive concentrations of resources, that allowing these special-interest collectives to participate in the political process would give them a huge comparative advantage over other interest groups, because in preparing for their economic role, corporations have already borne the heavy organizational expenses inherent in collective action. See M. Orson, The Logic of Collective Action 46-47 (1971). Although I have not found explicit reliance on this "transaction cost-imbalance" argument in the reform literature, but see C. LINDBLOM, supra note 6, at 194-98, it has frequently been suggested that, because corporations are artificial creations of the state, the state may properly limit them to the specific functions for which they were created. See infra text accompanying notes 30-31. 
underlying our democratic system fully justified the limitation on corporate speech. ${ }^{12}$ Nevertheless, the convergence of two controversial constitutional doctrines made the result in Bellotti almost inevitable. ${ }^{13}$ First, in Buckley v. Valeo, ${ }^{14}$ the Court had held that the government's attempt to limit an individual's political expenditures was a direct, impermissible abridgement of that person's free speech rights. The Gourt had made it clear in Buckley that a government purpose of equalizing expenditures cannot justify restricting first amendment rights. Second, in a line of cases starting with Bigelow v. Virginia ${ }^{15}$ and Virginia State Board of Pharmacy v. Virginia Citizens Consumer Council, Inc., ${ }^{16}$ the Court had rejected prior doctrine and held that the first amendment protected the speech of profit-oriented corporations. If the first amendment protects speech itself irrespective of its source, rather than people's freedom of speech, and if the first amendment outlaws even restrictions on speech that are designed to promote greater equality in electoral participation, then the result is Bellotti-a decision that establishes the corporation's right to participate in referendum, and perhaps electoral, campaigns. ${ }^{17}$ Critiques of Bellotti predictably will challenge one or the other of these doctrines. ${ }^{18}$

Virtually any first amendment theory would conclude that an individual's use of her resources to make or sponsor political communications is speech for first amendment purposes. ${ }^{19}$ The main

12435 U.S. at 802-22 (White, J., dissenting). For a similar analysis, see Baker, Commercial Speech: A Problem in the Theory of Freedom, 62 Iowa L. Rev. 1 (1976). A recent comment reaches the same conclusion and argues that "the Bellotti decision was unwise and should be overturned." Note, The Corporation and the Constitution: Economic Due Process and Corporate Speech, 90 Yare L.J. 1833,1834 (1981).

13 I do not discuss the possibility that the result in Bellotti can be justified as only a limited decision holding that the legislation was overbroad because it prohibited shareholders from voluntarily pooling their resources to promote their political views. See O'Kelley, The Constitutional Rights of Corporations Revisited: Social and Political Expression and the Corporation After First National Bank v. Bellotti, 67 GEo. L.J. 1347 (1979).

14424 U.S. 1 (1976).

15421 U.S. 809 (1975).

16425 U.S. 748 (1976).

17 The courts might limit Bellotti to ballot measures, see Bellotti, 435 U.S. at 788-92, but neither the marketplace-of-ideas concept nor the liberty theory provides a principled basis for the distinction. The predictable challenge to the federal prohibition on corporate contributions to candidates was recently filed. Washington Post, Nov. 26, 1981, § E, at 1-2, col. 1.

$18 \mathrm{~A}$ critique could also focus on the artificial nature of the corporation. See infra text accompanying note 30 .

19 But see Wright, Politics and the Constitution: Is Money Speech?, 85 YALE L.J. 1001 (1976) (criticizing the Court's determination in Buckley v. Valeo, 424 U.S. 1 (1976), that political contributions are speech protected by the first amendment). 
justification for governmentally imposed limitations on such speech is that these limitations promote equality of speech freedom, and thereby allow the political or speech "marketplace" to work better. The Supreme Court has consistently and properly rejected this justification. ${ }^{20}$ The government has no standard with which to identify a "properly working marketplace." ${ }^{21}$ Without such a standard, any restrictions necessarily would represent political choices among policy ends, or judgments concerning how to further the interests of particular groups. Therefore, one would expect that the restrictions, like more obvious censorship, would change in ways that further government policies or favor established political elites. Although such rationales provide the basis for most laws, and although the government's policy judgments may be reasonable, they are improper grounds for restricting speech freedom. First amendment protection of a realm of individual liberty (or-of a freely functioning marketplace of ideas, or of a legally unimpeded political process) rules out decisions to limit the effectiveness of some people's advocacy by limiting their speech freedom. Moreover, government-imposed restrictions on speech are particularly objectionable when they limit people's freedom to criticize the government. The permissible manner for the government to advance the egalitarian goal of promoting more equal access to the political arena is to increase either the egalitarian nature of our society generally or the access opportunities of those presently denied adequate access, rather than to restrict people's freedom to use their wealth to participate extensively. ${ }^{22}$ A government abridges

20 See, e.g., Citizens Against Rent Control v. City of Berkeley, 102 S. Ct. 434, 437 (1981); Buckley v. Valeo, 424 U.S. 1, 48-49, 54, 56-57 (1976); Miami Herald Publishing Co. v. Tornillo, 418 U.S. $24 I$ (1974); Columbia Broadcasting Sys. v. Democratic Nat'l Comm., 412 U.S. 94 (1973).

21 Professor Chevigny concludes, based on a careful assessment of the role of money in political campaigns, that "there is a compelling interest in regulating campaign expenditures [in order] to prevent distortion of the democratic process by money." Chevigny, The Paradox of Campaign Finance, 56 N.Y.U. L. REv. 206, 220 (1981); see id. 221, 225-26. The difficulty, though, is in defining a norm against which this "distortion" might be judged. For example, the most obvious potential standard-equal expenditures for each candidate or viewpoint-presents severe problems. Chevigny properly objects that "[a]ny effective [expenditure] limit [that was the same for incumbents and challengers] . . . would unfairly favor incumbents." Id. 221 (emphasis added); see id. 223; see also G. JAcoBson, supra note 10, at 213-14. If the primary function of elections is to measure support for different viewpoints or candidates rather than to find truth, enforced equality of expenditures arguably "distorts" the outcome. See Baker, Scope of the First Amendment Freedom of Speech, 25 U.C.L.A. L. Rev. 964, 983-90 (1978). This does not, of course, mean that existing unjust inequalities do not also "distort" the results.

22 For a more detailed critique of the "market failure" theories" of the first amendment, see Baker, supra note 21 , at $981-90$. 
speech freedom when it treats speech as a disfavored or impermissible use of resources.

An emphasis on "self-realization" surely justifies striking down the restrictions on speech involved in Buckley. Wealth generally increases people's options and opportunities to control their destiny in all areas of life. The wealthy usually are better situated to control their physical environment, to obtain educational opportunities, and to choose among recreational activities, as well as to engage in political speech and thus influence elections. An egalitarian concern for self-realization certainly justifies economic redistribution or more radical changes in basic economic arrangements. Nevertheless, when society permits people to have certain resources, it must allow them to use their resources for self-realization activities if it respects self-realization as a fundamental value. Even more clearly, society must allow those people to engage in particular self-realization activities, like speech, that receive special constitutional protection.

Assuming, then, that the Court was right to strike down expenditure limits in Buckley, criticism of Bellotti depends on showing that the source of the speech is constitutionally relevant. Any such critique must reject the conclusion that the first amendment protects the commercial speech of a profit-oriented corporation. If the importance of speech lies in its provision of information, analysis, or argument to the audience, as marketplace-of-ideas theorists assert, then the source of the speech is irrelevant. ${ }^{23} \mathrm{Re}$ gardless of its source, the information makes the same contribution or leads to the same distortions. In contrast, the difference in the sources of the speech in Bellotti and Buckley becomes crucial from the perspective of individual liberty-particularly the aspect that emphasizes people's participation in cultural, social, and political decisionmaking and change. The source of speech is also important from the perspective of a "self-realization" value-particularly the component of self-realization that emphasizes people's control over their destiny-although not according to Professor Redish's interpretation of the value. ${ }^{24}$ Political speech by a corporation, as in Bellotti, should not be protected, because these communications do not derive from the values or political commitments of any individuals.

Both defenders and critics of capitalist markets agree that a competitive free market system forces enterprises to adopt the most

23 See, e.g., Bellotti, 435 U.S. at 776-77, 783-84.

24 Redish, supra note 3 , at $620-21$. 
efficient, most profitable production and marketing techniques available. In a competitive context, consistent failure to operate efficiently would result in revenues being insufficient to cover costs, and thus eventually in bankruptcy, a very effective disciplinary measure. Defenders of the market praise this enforced efficiency, whereas critics sometimes condemn its coercive operation. The key point here, however, is that the market mechanism, by forcing the enterprise to make the most efficient (profit-maximizing) decisions, dictates the content of the enterprise's speech, and thus separates the decision concerning speech content from the value decisions of either the employees or the owners of the enterprise. As long as the market structure, rather than individual choice, controls the enterprise's decisions, that is, as long as the market structure (or the legal order) mandates that the decisions be profit-oriented, human control over our destiny will depend on the right and ability of people collectively to overrule or to regulate the market and to control directly the content and structure of corporate decisionmaking. ${ }^{25}$

For example, in order to maximize its profits, and possibly in order to survive as an ongoing enterprise, a cigarette, liquor, or nuclear-power company must successfully promote particular decisions and attitudes, including the desirability of using its products, irrespective of the personal values of its shareholders, managers, and workers. Although the corporation's product advertising and political advocacy help form our future, any relationship between the content of its messages and individual values is coincidental. The content of the advocacy results not from individual choice, but from the structural dictates of the market.

An individual's personal values may lead her to make or sponsor messages with content identical to market-dictated speech. Because the self-realization interpretation of the first amendment protects people's use of speech to advance their own values, it would not permit a ban on such an individual's speech; a ban on all messages of a particular content would be inconsistent with the self-

25 For a more detailed elaboration of this analysis, see Baker, supra note 12 . This analysis provides a theoretical basis for concluding that constitutionally protecting the speech of the profit-oriented enterprise involves a return to the Lochner era of economic due process, a conclusion reached both by Professors Jackson and Jeffries with respect to the enterprise's product- or business-related advertising and by a recent Yale Law Review Note in relation to the enterprise's political speech. Jackson and Jeffries, Commercial Speech: Economic Due Process and the First Amendment, 65 VIRGINIA L. REv. I (1979); Note, supra note 12; see also Central Hudson Gas v. Public Serv. Comm'n, 447 U.S. 557, 589-90 (1980) (Rehnquist, J., dissenting); Emerson, First Amendment Doctrine and the Burger Court, 68 CALIF. L. REv. 422, 458-61 (1980). 
realization value. ${ }^{26}$ However, that first amendment protection results when the individual chooses this speech as an aspect of selfrealization does not imply that the government may not regulate or ban the enterprise's identical message. In fact, people's power collectively to regulate the otherwise autonomously operating enterprise increases human freedom. Regulation of commercial speech is permissible unless the sponsor claims that the enterprise's speech is an exercise of her personal freedom rather than the enterprise's response to market dictates. Government regulation is perfectly proper unless the speaker or sponsor treats the message as an act of personal consumption, as a use of her resources to advance her ends, rather than as the enterprise's profit-oriented activity.

The government could institutionalize this distinction between personally chosen speech and market-dictated speech by requiring an individual speaker or sponsor who claims a personal interest in a message to treat the message as a personal expenditure rather than a business expense for income tax purposes. When the sponsor is a profit-oriented corporation, the government could ban the speech unless the corporation shows that the message represents the personal choices and expenditures of individuals. For example, the government could require the corporation to provide a checkoff consent procedure that would give each stockholder a choice between receiving a cash dividend or making a contribution to the corporate "speech" fund. For tax purposes, the government could require the stockholder to treat the "contribution" as income and as a personal, nondeductible expenditure. ${ }^{27}$ The government could even totally prohibit the corporation's involvement in setting up such a fund, although it must allow individual stockholders (or workers) to set up collective funds and organizations for advocacy and other activities.

The argument that market-dictated speech does not represent individual choice or self-realization activity applies without modification to the corporate political speech in Bellotti. ${ }^{28}$ Governmental regulation of such speech would not interfere with any in-

${ }^{26}$ In his dissent in Virginia State Bd. of Pharmacy v. Virginia Citizens Consumers Council, Inc., 425 U.S. 748, 782-83 (1976), Justice Rehnquist emphasized that the law prohibiting pharmacists from publishing price information did not apply to consumer groups collecting and publishing the same information.

27 See Baker, supra note 12 , at 37.

28 Justice Douglas noted in Bell v. Maryland, 378 U.S. 226, 245-46, 265-70 (1964) that the corporate decision to discriminate against blacks was not motivated by any personal prejudice, but only by a need to earn a profit. The history of corporate political contributions exhibits the same predictable orientation. See, e.g., L. OverACKER, supra note 4, at 177-88; E. Sikes, supra note 11, at 107-13. 
dividual speaker's self-realization attempts. ${ }^{29}$ Moreover, when social structures such as economic markets operate to promote structurally determined values, human self-determination-people's ability to control their destiny-depends on the right and the ability of people collectively to control, regulate, or restructure the autonomous workings of these social structures. In other words, the self-realization value requires that people be permitted to act collectively to regulate the corporate political speech in Bellotti.

Even if one were not convinced that the market structure dictates the choices of profit-oriented enterprises, and thus that there is no necessary connection between commercial speech and the "speaker's" freedom, a focus on individual freedom would still allow, if not require, a prohibition on corporate political speech. In his dissent in Bellotti, Justice Rehnquist echoed one theme of early supporters of the ban on corporate contributions: that corporations are artificial entities that have no claim to constitutionally protected liberty. ${ }^{30}$ The state could reasonably require that these artificial entities engage in speech only to further the limited commercial purposes for which they were created. The state could also reasonably regulate the manner in which the corporation engages in commercial speech. Of course, the corporation's political speech may serve its interests in making a profit as well as or better than does the corporation's product advertising. Nevertheless, the business corporation is not chartered to engage in politics. Restrictions on its political speech would be merely one of many ways in which the law sets the parameters of the corporation's permissible business conduct. $^{31}$

The Court's refusal to sustain the regulation at issue in $\mathrm{Bel}$ lotti must be seen as entirely unprincipled given that the Court has upheld corresponding limitations on labor unions in order to protect their dissenting members. ${ }^{32}$ Protection of dissenting union 783-84.

28 The Bellotti majority apparently accepted this view. See 435 U.S. at 776-77,

30435 U.S. at 825-27 (Rehnquist, J., dissenting); see also id. 809 (White, J., dissenting).

31 Prohibiting corporate political speech also advances one of the fundamental purposes of the original corporate regulatory legislation-protecting the liberty of the dissenting shareholders-and it does so without limiting the freedom of speech of the nondissenting shareholders. Bellotti, 435 U.S. at 818-21 (White, J., dissenting); Bolton, Constitutional Limitations on Restricting Corporate and Union Political Speech, 22 Arrz. L. REv. 373, 375-81 (1980).

32 This arguably overstates the inconsistency. Although formally both stockholders and employee union members are free to exit if they disagree, most would agree that in general employees are actually more restrained. Nevertheless, it is not clear how the cases differ in terms of the constitutional permissibility or neces- 
members is not only permitted, ${ }^{33}$ in some contexts it is constitutionally required. ${ }^{34}$ Although this protection, like the protection implicit in the law in Bellotti, may result in limiting the total quantity of speech, such regulation (like the regulation in Bellotti) arguably protects individual freedom or "self-realization." Given these precedents, the Bellotti decision appears to reflect an unprincipled preference for corporate over union speech. In fact, the differences between the two contexts suggest that the Court may have it backwards-if either the corporation or the union has a constitutional claim for protection of its political speech, it is the latter. ${ }^{35}$ But even without relying on an argument that union

sity of protecting the dissenting party's associational or speech concerns. Indeed, there are some good reasons for concluding that the restriction on the collective's speech is more justifiable as a means of protecting the dissenting shareholder than the dissenting union member. See infra note 35.

${ }^{33}$ See, e.g., International Ass'n of Machinists v. Street, 367 U.S. 740 (1961). The relevant parallel to the Court's leaving open the question whether protection of the dissenting union member is constitutionally required would have been for the Court to have left open whether the law at issue in Bellotti was constitutionally required or merely a permissible legislative reform. Either alternative would, of course, have necessitated a different result in that case.

34 Abood v. Detroit Bd. of Educ., 431 U.S. 209, 232-35 (1977).

35 Unlike in the typical corporate shareholder context, union members are in relatively frequent contact with each other and are better situated to exercise real control over the union's decisions and expenditure policies. Politics is alive in the union-at least more so than at the corporation's annual meeting. This difference is not only confirmed by observation but is also predicted by theory. See A. HIrschman, Exir, Voice, and Loyalty 79-80, 84 n. ${ }^{\circ}$ (1970). The union, with a one-person, one-vote practice, is much more like a local government than like the typical profit-oriented corporation. Compare Kramer v. Union Free School Dist. No. 15, 395 U.S. 621 (1969) with Ball v. James, 451 U.S. 355 (1981).

In the political context, the right to vote and the freedom to use one's untaxed wealth for personally chosen expressive purposes together protect liberty while allowing coercively (tax-) supported governmental speech; a similar result is arguably appropriate in the union context. Given its democratic government, the union's decisions concerning how to spend its coercively collected dues should be given as much protection as the speech-related decisions of local governments. See Anderson v. City of Boston, 376 Mass. 178, 380 N.E.2d 628 (Mass. 1978) (holding that the state had barred a municipal corporation from making certain political expenditures and that this prohibition was constitutional), appeal dismissed, 439 U.S. 1060 (1979). Applying the Anderson analogy to the union context might suggest that Street was right but Abood was wrong. For an excellent discussion of the problems of the dissenting-taxpayer model as a justification for a constitutional mandate to limit government speech, see Shiffrin, Government Speech, 27 U.C.L.A. L. REv. $565,588-95$ ( 1980$)$.

From a more pragmatic perspective, Charles Lindblom, hardly known as a radical, concludes his book Politics and Markets with the suggestion that: "More than class, the major specific institutional barrier to fuller democracy may therefore be the autonomy of the private corporation .... The large private corporation fits oddly into democratic theory and vision. Indeed, it does not fit." C. LINDBLoM, supra note 6 , at 356 . Lindblom rejects any suggested parallel between union and corporate political involvement. Id. 193-99. He argues that of the two major control systems, electoral and business decisionmaking, corporate interests directly dominate one system and in the other "enjoy a triple advantage" over other groups of citizens by virtue of their extensive organizational advantages, their special access 
political speech should be more protected than corporate speech, or on the claim that the two are not symmetrical because the union's speech, unlike the corporation's, is not market-determined, ${ }^{36}$ the corporation's speech still should be at least as subject to regulation as the union's-which indicates that Bellotti is out of line with precedent.

Redish apparently ${ }^{37}$ would challenge these conclusions. His analysis of the contribution of speech to self-rule, and thus to selfrealization, is not tied to the importance of the freedom of the speaker, which was the crucial consideration in the above analysis. The Court and (to a lesser extent) Redish appear to accept the argument that corporate speech has little relation to the sponsor's selfrealization or liberty or individual choice. Instead, both Redish and the Court focus on the listener. Their approach justifies protection on classic marketplace-of-ideas reasoning: corporate speech provides information that the listener may need and use in finding "truth"-or, more plausibly, in making informed decisions. ${ }^{38}$ Redish subsumes this marketplace value of speech under his selfrealization value because of the possible contribution that corporate speech may make to the listener's self-realization. ${ }^{39}$ Presumably

to government, and their control over extraordinary financial resources, a power that "has no rationale in democratic theory." Id. 194. This strong democratic justification for limiting corporate executive power to use stockholder assets in electoral politics pales any attempted comparison with arguments for restricting unions' use of their assets for political purposes.

36 See infra note 87.

37 Redish clearly treats corporate speech as deserving protection because it provides information. Redish, supra note 3 , at 630 . Nevertheless, one cannot be certain without more information whether Redish, as a first amendment balancer, will come up with new considerations that favor denial of such protection in some particular contexts.

38 Redish emphasizes this revision of the marketplace-of-ideas theory: that speech deserves protection merely because it might affect some decision. Redish, supra note 3, at 617-18. This revision, however, creates more problems than it solves. For example, without any external standard such as truth to which free speech may be thought to lead and without some mechanism such as rationality with which people may identify the relevant information, one must expect that the quantity and packaging of information are major determinants of effect. Therefore, the revision intensifies the problem of the imbalance of speakers' influence. Collective decisions will more obviously reflect the ability of different groups to propagate their views; market power in the interrelated marketplaces of wealth and of ideas, rather than collective welfare or rationality, will determine outcome. Decisions in the idea or policy marketplace will be as arbitrary and unjust as the existing distribution of wealth and other sources of power, and will even lack legitimacy as accurate expressions of democracy. Cf. supra note 21.

39 Redish, supra note 3, at 617-18. Because it is possible to relate almost any desirable feature of any practice to self-realization, by itself this value may be useless as a constitutional guide. Alternatively, this all-encompassing quality may indicate that the crucial issue is how to interpret and implement this value. 
Redish would defend Bellotti specifically-as he defends freedom of corporate speech generally ${ }^{40}$-on the ground that the communications of these entities contribute to the listener's self-realization.

\section{Redish's Elaboration of the Self-Realization Value}

Redish emphasizes that "the constitutional guarantee of free speech ultimately serves only one true value, ... 'individual self-realization,' " 41 but he quickly indicates that this self-realization value has two components: first, "development of the individual's powers and abilities" (self-development), and, second, "control of [one's] own destiny through making life-affecting decisions" (self-rule). ${ }^{42}$ This breakdown corresponds closely to my presentation of a liberty theory of the first amendment, which emphasizes that the protected liberties promote self-realization (compare Redish's self-development component) and self-determination (compare Redish's selfrule component), and which repeatedly emphasizes people's selffulfillment and participation in societal change. ${ }^{43}$ The two theories, however, differ in their elaboration of these values.

Redish argues that speech directly fosters self-development but only indirectly fosters self-rule. ${ }^{44}$ Speech indirectly fosters self-rule by providing "a free flow of information and opinion to guide [people] in making . . . life-affecting decisions." 45 In contrast, the liberty theory argues that the first amendment protects verbal and nonverbal conduct because that conduct, in addition to its direct contribution to self-development, directly "constitute[s] an exercise of one's ability to make life-affecting decisions" 46 and to participate in the collective activity of controlling our destiny. ${ }^{47}$ A person's expressive behavior both directly defines or constitutes the person and is the person's major noncoercive, "direct" method for affect-

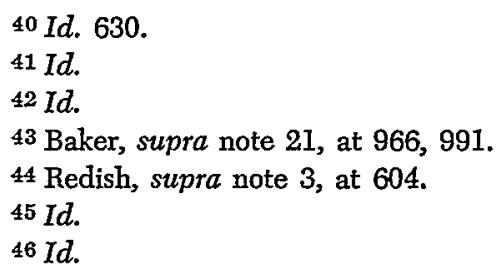

47 Redish's suggestion that the liberty theory does not recognize the self-rule component of the self-realization value, $i d$. 620 , despite my continual emphasis of this element, can only be explained as a manifestation of his unwillingness to consider seriously the possibility that the first amendment directly protects self-rule: that the first amendment protects acts of individual self-governance and participation in controlling collective destiny, rather than access to some particular resources that might be useful to one engaged in self-rule. Thus, Redish appears to take my refusal to base constitutional protection on a communication's indirect contribution to self-rule as a rejection of the value itself. 
ing the rest of the social world. From this view, the crucial reason to protect speech-as well as assemblies, associations, and practices dictated by religion or conscience, and, more generally, all valuebased, self-expressive conduct-is that it has a direct role in controlling or influencing our destiny.

One's choice between these alternative interpretations of the first amendment's contribution to self-rule-as either direct protection or indirect fostering-determines one's view of Bellotti. If the first amendment protects speech only in its direct contribution to self-rule, then the corporation's market-determined speech has no claim to protection. If, however, the constitution protects speech whenever it provides any information that might be useful to the listener's self-rule, then Bellotti was correctly decided. Because the practical implications of these theoretical alternatives are far-reaching, Redish's "proof" of the correctness of his choice to emphasize the indirect contribution of speech must be examined.

Redish claims that the centrality of self-realization and, apparently, his particular elaboration of this value "can be proven ... by reasoning from what we in this nation take as given: our democratic system of government." 48 An argument for first amendment rights premised on our acceptance of democracy could take either of two forms, and here Redish makes the right choice. First, an analysis founded on the assumption of democracy might treat first amendment rights only as means necessary, or at least helpful, for the proper functioning of a democracy. The analysis proceeds directly from democracy as an end to free speech as a necessary means. But without the introduction of value assumptions beyond the mere desire for democracy, this means-analysis does not indicate when to protect speech. For example, the mere premise of democracy cannot show why speech is needed for democracy, how important particular speech rights are, or why a democratic choice to restrict speech is invalid.

Redish quite properly follows a second analysis that does bring in added value assumptions. He claims to show, first, "that the moral norms inherent in the choice of our specific form of democracy logically imply the broader value, self-realization," 49 and, second, that this broader value of self-realization leads to his first amendment theory. ${ }^{50}$ Redish argues that we accept democracy be-

48 Id. 594.

49 Id.

$60 \mathrm{Id}$. 
cause it uniquely fosters certain values ${ }^{51}$-namely, self-rule and selfdevelopment-and that the commitment to these values that is implicit in our acceptance of our form of democracy "logically" requires that we also protect speech that contributes to these values. Thus, free speech rights are not implied by democracy itself but by the values that justify democracy. ${ }^{\mathbf{6}}$

Briefly, then, Redish claims that: (1) democracy is a means of achieving both the "intrinsic" value of self-rule and the "instrumental" value of human development; (2) both values can be achieved by other means; and (3) these values justify free speech when and because free speech directly fosters human development and indirectly fosters self-rule..$^{53}$

Unfortunately, these assertions by themselves present little reason to accept Redish's claim that his first amendment theory follows logically from our acceptance of democracy. His theory so follows only if promoting the self-realization value, as he interprets it, is the only, or at least the best, explanation for our acceptance of democracy; otherwise, acceptance of democracy might be consistent with, yet not "logically" commit one to, the broader value, self-realization. Measured by this standard, one part of Redish's derivation quickly breaks down. Although democracy may further the "development of the individual's human faculties," 54 a concern with self-development does not in any obvious way require a democratic political order. More relevantly in terms of Redish's purposes, one might accept democracy for reasons other than a concern for individuals' development of their facultiesfor example, because of the importance we place on self-rule. Thus, Redish fails to show that our acceptance of democracy logically implies acceptance of the self-development value or that this value underlies the first amendment. Note, however, that even if one cannot persuasively derive a commitment to human development from an acceptance of democracy, this failure does not show that the self-development value is not central to the reasons we protect

51 Id. 601-02.

52 Failure to recognize that the basic premise is not democracy but the normative theory that justifies democracy often leads to confusion. For example, if democracy itself is basic, limits on democracy become difficult or impossible to justify. In contrast, a normative theory that justifies general reliance on democracy may also justify specific limits on that democracy; in particular, the necessity that the public order respect individuals' autonomy and equality might require both democracy and limits on democracy. See Baker, Counting Preferences in Collective Choice Situations, 25 U.C.L.A. L. Rev. 381 (1978).

${ }^{53}$ Redish, supra note 3, at 603-04.

54 Id. 603. 
speech. Rather, it only shows that the claim that this value is central needs support from considerations beyond our acceptance of democracy.55

As the above comments suggest, the self-rule value better meets the needs of Redish's derivation. A commitment to self-rule at least suggests, and arguably requires, democracy of some form. More to the point, a commitment to self-rule may provide part of the best normative (although not necessarily the best historical) explanation for our acceptance of democracy-or at least for our increasing, but inadequately realized, acceptance of democracy. Therefore, the following discussion will ignore the self-development value and instead focus on the way Redish elaborates the self-rule value-an elaboration that would justify the Court's decision in Bellotti.

Redish's crucial claim, then, is that the self-rule value justifies constitutional protection of free speech. The persuasiveness of this claim depends on how one connects free speech with self-rule. One could emphasize that a person's freedom to engage in speech and other self-expressive activities-the person's exercise of her liberty-is an important aspect of self-rule and a key method by which the person participates in collective decisionmaking. From this perspective, freedom of expression, like democracy, is constitutive of self-rule; the "direct fostering" "50 of self-rule is key.

Alternatively, the self-rule value may lead us to protect speech because of the importance of providing information that may be used in public and private decisionmaking. This argument stresses that individuals cannot control their destiny without a free, unimpeded flow of information. ${ }^{57}$ At least three considerations, however, undermine the persuasiveness of this interpretation of the freedom-of-speech guarantee. First, both self-rule and democracy can and do operate without full or complete information. In fact, it is unclear why full and complete information should have a particularly high status among all the goods or resources instrumentally useful to self-rule. ${ }^{58}$ Nor does the importance of self-rule obviously

55 Redish and I agree on the importance of the speaker's use of speech for self-development; our differences on this point lie only in how we arrive at a first amendment interpretation that emphasizes this function.

56 See Redish, supra note 3, at 604.

57 See, e.g., id. 621 ("II]f an individual is given the opportunity to control his destiny ...., he or she needs all possible information that might aid in making these life-affecting decisions."); see also id. 618.

58 One possible answer-that the Constitution's text gives this status to free access to any speech or writing that provides information-can be quickly dismissed. First, it is generally recognized that citizens have no constitutional right to infor- 
imply that providing more information justifies routinely overriding collective, democratic, presumptively welfare-promoting self-rule decisions. Certainly, public and private decision-making does occur, and given the limits of the human mind, must occur, with less than full information.

Second, even if supplying information to the listener usually promotes self-rule, this "indirect" support does not distinguish the information's contribution from the contribution made by various other resources and opportunities, such as food, shelter, health care, and employment and educational options. One could reasonably suspect that the contribution to self-rule resulting from increased communications by nonmedia, ${ }^{69}$ profit-oriented corporations is less significant than the contribution that would be made by increases in education, rights of access to privately or governmentally held information, or research expenditures aimed at producing more information. All of these indirect supports may make self-rule more rational, more informed, and more valuable. Each also has a cost. From the perspective of individual self-rule-as opposed to the marketplace-of-ideas perspective-it is unclear why one contributing resource, information, should receive special protection. Although there is an explicit constitutional judgment concerning the importance of freedom of speech, this does not mean that all provision of information should be protected. The text of the Constitution does not itself show whether the first amendment's focus is on the provision of information or on the individual's freedom (a freedom that will, among other things, result in a broad stream of often relevant or useful information). ${ }^{60}$

In attempting to derive constitutional guarantees on the basis of the contribution of a resource to self-rule, one suspects that a guarantee of a good education would make a more significant "indirect" contribution that would protection of corporate adver-

mation from either private or public sources merely because the information would be useful to their self-rule. Private parties in most circumstances are free to choose not to speak, and both public and private parties may be legally (for example, contractually) prohibited from speaking under certain circumstances. Second, the Constitution's text refers to "freedom of speech," which suggests that the freedom of the speaker is the central concern. Third, assuming (as I do) that the protected freedom extends also to the listener or recipient, there is no obvious, and certainly no textual, reason to treat this as anything more than freedom to receive communications that others who have a right to speak decide to make available. See Baker, supra note 21, at 1007; Baker, supra note 12 , at 8 . This possibility apparently did not occur to Redish. See Redish, supra note 3 , at 620-21. In any event, a textual argument presumably would be irrelevant to Redish's overtly normative attempt to derive freedom of speech from democracy, see id. 593-94.

59 The press may have a special claim to constitutional protection based in part on its information-supplying role. See infra note 69.

${ }^{60}$ See supra note 58. 
tisements. $^{\text {e1 }}$ Even if information were the appropriate focus, the protection that Redish supports may be less important than those he ignores. As long as the first amendment protects a free press and the individual's right to speak, most information and argument that the corporation would subsidize will be made available anyway, although probably with different packaging and in different quantities. Giving individuals a first amendment right of access to all government- and corporate-held information would arguably advance self-rule more than would a right of corporations to choose what information to subsidize. Both rights would promote a "free flow of information," ${ }^{2}$ but the first provides for information that people specifically want and that they might not otherwise be able to obtain.

These various rights to resources would, under various circumstances and at different costs, make varying contributions to selfrule. The indeterminacy of these possible contributions strongly suggests that this indirect support is an inadequate basis for a constitutional right to, as opposed to legislative provision of, the resource. Although egalitarian notions, properly formulated under equal protection rubrics, may require provision of some minimal level of some or all of these instrumental supports of self-rule, ${ }^{63}$ we generally accept legislative choices about how to balance the costs and benefits of providing these indirect supports in particular amounts or particular ways. Our acceptance of democracy arguably commits us to acceptance of such "self-rule" decisions.

A third consideration also militates against Redish's elaboration of the self-rule value. Any justification for protection built on the contribution that corporate speech makes to individuals' self-rule is unpersuasive as long as it remains an open empirical and normative question whether this additional information actually promotes rational, intelligent self-rule. The additional speech might in fact detract from self-rule by contributing to information overload, by supplying an ideologically unbalanced and distorted background, or by promoting simplistic thinking. If speech's instrumental contribution to self-rule provides the justification for

01 Cf. San Antonio Indep. School Dist. v. Rodriguez, 411 U.S. 1, 35-36 (1973) (discussion of the contribution of education to intelligent use of the franchise).

02 Of course, the legal rules may affect what information is produced and how it is stored and communicated. Just as rules granting corporate free speech will have various effects on who produces and communicates what information, guaranteed access rules would have diverse effects.

63 See, e.g., Michelman, The Supreme Court, 1968 Term-Foreword: On Protecting the Poor Through the Fourteenth Amendment, 83 Harv. L. Rev. 7, 9 (1969); Baker, Outcome Equality or Equality of Respect: The Normative Content of Equal Protection (unpublished). 
protecting speech, then at least the protection ought to depend on whether the speech does so contribute. The difficulty or impossibility of determining whether a particular category of speech contributes to self-rule only emphasizes that the justification for first amendment protection must rely on considerations other than speech's indirect or instrumental contribution.

Questions about whether a type of speech contributes usefully to the audience's decisionmaking are irrelevant if free expression is viewed as a constituent aspect of self-rule. Prohibiting an individual from speaking or from reaching a willing audience amounts to a direct abridgement of that individual's self-rule and of her participation in collective self-rule. According to this interpretation, as long as attempts to regulate information flows occur in ways that do not abridge individuals' self-expression, these attempts, like collective decisions relating to education and other social supports for self-rule, are permissible-and may make important contributions to intelligent, informed, and active self-rule. Precisely this conclusion-that restrictions on corporate political speech would contribute to self-rule-explains the decision made by the federal and most state governments to restrict corporate political speech.

Acceptance of the self-rule value as the basis of the analysis thus does not necessarily imply protection of information flows. Self-rule can exist without such protection. Moreover, self-rule no more requires protection of information flows than it requires protection of a variety of other indirect supports of self-rule. Finally, protecting the increased information flow rather than individual liberty may, in certain cases, undermine rather than contribute to self-rule. Rather than focusing on the protection of information that may indirectly support the listener's self-rule, the better, more straightforward elaboration of the self-rule value is to view it as primarily requiring protection of self-expressive conduct -that is, protection of the liberty of the speaker or actor. Redish's elaboration of self-rule takes the other, less persuasive approach.

Redish deals with the same issue, the relation between free speech and self-rule, when he explains his claim that few would disagree with Meiklejohn's "logic." Meiklejohn concluded that " $[t]$ he principle of the freedom of speech ... is a deduction from the basic American agreement that public issues shall be decided by universal suffrage." ${ }^{84}$ The persuasiveness of Meiklejohn's con-

64 A. MEIKLEJOFN, Polrticar FREEDOM 27 (1960) (expanded version of Meiklejohn's Free Speech (1948)), quoted in Redish, supra note 3, at 596. 
clusion depends on how one interprets the "deduction." First, it could be interpreted to mean that, if people have a right to participate in deciding public issues, this right must encompass several more specific rights: for example, the right to advocate their view of the proper solution, the right to search out and communicate relevant information, perhaps the right to engage in behavioral "voting" when that is an appropriate way to make a social or cultural decision, and the right to decide on any basis they want (with the possible limitation that a government decision cannot embody a judgment inconsistent with the reasons we value democracy). ${ }^{68}$ These subsidiary rights are not means to further the basic right, but instead constitute or provide the meaning of the basic right. This deduction from our acceptance of democracy thus leads to the liberty theory of the first amendment. ${ }^{.7}$

Second, one could interpret Meiklejohn's deduction to mean that, if people have a right to participate in deciding public issues, they ought to be able to exercise this right wisely or meaningfully, and wise or meaningful exercise of the right requires one or more additional rights: for example, rights to a good education, enough resources or power to make one's choices meaningful, and the most informative possible flow of information. This last additional right might be implemented by granting any of several even more specific rights: a right of access to government-held information; a right to have the government encourage research designed to gain new information; a right to forbid governmental attempts to structure the flow of information; or, conversely, a right to choose collectively to structure the flow of information in ways expected to aid people's efforts at self-rule. Unfortunately, it is unclear which of these additional rights is most important, or how much of each is sufficiently important, as a component of a theory of democracy, to justify overriding democratically arrived-at choices.

Redish apparently believes that few would disagree that our acceptance of democracy necessarily leads to the second deduction and to the particular corollary right that he thinks makes self-rule meaningful: the right to be free from all governmental restrictions

65 People can "vote" in favor of a particular social environment either with ballots or with behavior that itself helps to create the desired environment. Maximizing liberty will often require reliance on the second form of "voting." Baker, supra note 52, at 403-05.

66 See Baker, supra note 65.

67 Of course, neither this nor the next deduction shows how one moves from the single premise of democracy to any limitation on majority rule. One needs a more expansive theory for that task. 
on the flow of information (at least from private sources), even from restrictions that do not violate anyone's liberty interest and that the collective has concluded would advance self-rule. ${ }^{88}$ Apparently, I am one of the few. ${ }^{69}$ I find the first deduction almost compelled. The right of popular participation in collective decisionmaking-or the broader right of self-rule-must have some meaning. The first deduction's description of the essential content of self-rule (beyond the mere right to vote) is quite plausible, and is roughly the content that our practices have actually given to the right. In contrast, the second deduction refers to the obvious fact that, at varying costs, we can find various ways to make popular participation more meaningful or more desirable. Of course, people will reach different conclusions, sometimes conclusions opposite to Redish's, concerning how to make popular participation more meaningful or how indirectly to advance self-rule. Many have apparently concluded, for example, that passage of laws restricting corporate political speech would advance self-rule. ${ }^{70}$ In

${ }^{68}$ Meiklejohn argued that "[w] but that everything worth saying shall be said," A. MEIKLEJOHN, supra note 64 , at 26 , indicating that he, like Redish, believed that information rather than individual liberty is the key to the first amendment. Nevertheless, Meiklejohn and Redish differ in their elaborations of this general emphasis on information. The quoted statement suggests the possibility, made explicit elsewhere, that Meiklejohn would permit regulation of speech that is merely repetitious or that is disruptive of mature deliberations. See, e.g., id. 24-27. Meiklejohn thus apparently rejected Redish's conclusion that the government must not inhibit the flow of information and opinions, see Redish, supra note 3, at 617-18. Indeed, to the extent that the government regulates corporate speech under the reasonable assumptions that all viewpoints will be advocated as long as individuals' freedom of speech is protected and that the regulation will only reduce the frequency with which one view will be repeated, and justifies the limitation as a means to prevent disruption and to promote better and more equal consideration of all views, Meiklejohn might approve of the regulation. See Note, supra note 12, at 1857 . Nevertheless, this divergence in Redish's and Meiklejohn's "deductions" speaks less to the relative merits of alternative approaches to information flows and more to the uninformative nature of a constitutional analysis (as opposed to a policy analysis) that focuses on provision of information as a means to advance some other goal. But see infra note 69.

69 But see Baker, Press Rights and Government Power to Structure the Press, 34 U. MiamI L. REv. 819 (1980).

The public availability of information, particularly information that could expose government abuse or check government power, would make a very important, instrumental contribution to both our welfare and freedom. Generally, the justification for any institution is either its embodiment of, or its contribution to, human values. An adequate explanation for our Constitution's giving the commercial press a special status as a constitutionally identified institution lies in the press's important role in providing information, opinion, and perspective. This consideration suggests, as I have argued elsewhere, id. 828-36, that Professor Blasi's emphasis on the checking value, Blasi, The Checking Value in First Amendment Theory, 1977 AM. B. Found. RESEARCH J. 521, should be used in interpreting the press clause in particular rather than the first amendment as a whole.

${ }^{70}$ See supra note II and accompanying text. 
any event, the basic right of participation does not provide a very forceful reason to choose any particular way of fostering participation.

This same movement from the plausible premise of self-rule to an undefended conclusion about how self-rule should be elaborated continually reappears in Redish's article. Redish argues, for example, that the individual has a right to make many decisions and that this right must mean that the individual can make the decisions on irrational grounds. ${ }^{71} \mathrm{He}$ also concludes that "the individual needs [and has a right to] an unihibited flow of information and opinion." 72 "[A]Il such expression" should be protected, because any expression of information or opinion will "potentially affect some ... decision at some point in time" "73-and so, one might add, will any resource allocation made by either the government or private individuals, or any activity or experience that an individual has. One is tempted to retort that, if it does not matter if an individual makes decisions on the basis of irrational appeals, then it should not matter how much or what information a person has; the right to make life-affecting decisions, therefore, implies nothing about the need for an uninhibited information flow. A better response, however, is that our practices distinguish the duty of the collective to leave many decisions in individuals' hands, and thus to allow individuals to decide on whatever basis they choose, from the interest of the collective in passing laws or encouraging practices that may increase the rationality and wisdom with which individuals exercise that freedom. Provision of public education is one expression of a collective interest in influencing information flows and in increasing the individual's capacity to make decisions rationally while leaving the ultimate decision to the individual. The collective's respect for individual liberty, which does not require an uninhibited flow of information and is not infringed by regulation of corporate speech, best describes our practices and our commitment to democracy.

\section{JUSTIFYing A Constitutional INTERPRETATION}

Any theorist could argue that her favored interpretation of the first amendment promotes self-realization-the value is simply too broad and congenial to establish limits. A value that will justify anything is of little help: an informative theory must

71 Redish, supra note 3, at 618.

72 Id.

73 Id. 
describe and defend specific elaborations of such general values. Redish attempts to do this by focusing on our acceptance of democracy, but his elaboration is unpersuasive. Redish first suggests that acceptance of democracy indicates the importance of self-development and self-rule. Although most people would probably agree on the importance of the "development of the individual's human faculties," 74 and many might agree that some forms of democratic political practices contribute to this goal, our acceptance of democracy does not commit us to this goal. Other values can and do explain our acceptance of democracy.

Although the self-rule value is more closely connected to our acceptance of democracy, Redish does not explain why we should accept his elaboration. Redish's view that the self-rule value justifies protection of speech because the speech may indirectly contribute to individual decisionmaking contrasts poorly with the view that self-rule justifies protection of individually chosen self-expressive conduct because this conduct constitutes an important aspect of individual self-rule and a key, noncoercive, nonviolent aspect of the individual's participation in collective self-rule. The plausibility of this second view indicates that, even if one begins at Redish's starting point, one can easily arrive at the "liberty theory" of the first amendment rather than at Redish's theory. Thus, starting with the self-rule value can lead to theories that diverge completely, for example, in their view of the permissibility of regulating corporate political speech. Although only a careful examination of the liberty theory could show whether its alternative elaboration of the self-rule value provides a preferable guide for interpreting the first amendment, ${ }^{75}$ a suggestion of the types of considerations relevant for such an inquiry will serve as a conclusion to this comment.

First are considerations related to one's view of the basic function of our constitutional structure. If the Constitution's primary role is seen as allocating decisionmaking authority and defining power relations among branches and levels of government and between the government and the individual, then one would probably view first amendment rights as protecting certain decisionmaking

\section{$74 I d$.}

75 See Baker, The Process of Change and the Liberty Theory of the First Amendment, 55 S. CAL. L. Rev. 293 (1982); Baker, supra note 21. I do not claim to provide a comprehensive defense of the liberty theory in this comment. Even my articles cited above need to be supplemented with a more explicit defense of the method of interpretation upon which they rely before I can claim to have provided a complete argument. 
authority of the individual against government interference. ${ }^{76}$ In contrast, interpreting the Constitution as designed to promote certain allocations of resources (such as information and opinion), in order to further certain goals (such as informed decisionmaking), is more questionable. This approach will inevitably lead to balancing, as it does for Redish, and will require the judiciary to engage in legislative-type decisionmaking. Whether specific regulations and allocations advance particular goals, how well they advance them, and whether the gain is worth the cost, are questions whose answers normally change with time and context, and which we usually leave to the legislative arena.

Second, consideration of various practices to which we are committed and the values that best explain these commitments may support particular constitutional interpretations. Redish properly attempts to derive his proposed limits on democracy not from democracy itself, but from the values that best explain our acceptance of democracy. This may be all that one can do. As Wiggenstein remarked, at some point giving further "grounds" must come to an end, although "the end is not an ungrounded presupposition; it is an ungrounded way of acting." 77 Still, one can look to see if any other considerations, any of our other practices or value commitments, can further explain and define our acceptance of either democracy or free speech. Given the uncertainty concerning what one should deduce about free speech from our acceptance of democracy, finding further considerations, including the approaches to constitutional interpretation mentioned in the previous paragraph, seems particularly urgent if we are to describe adequately the proper scope of free speech.

That no moral duty to act in a particular way arises solely from coercion or threats is probably even more deeply embedded

76 Redish's claim that the government should not have authority to restrict information Hlows, Redish, supra note 3 , at $617-18$, does not put his approach into this category. In that part of his argument, Redish does not claim that individual choice generated the information flow. Thus, protection of market-determined corporate speech would not be an allocation of decisionmaking authority to individuals rather than government, because neither would control the expression. Rather, the ultimate determinant of the content of corporate speech is the market structure, which we generally agree is properly subject to collective control, see, e.g. Jackson \& Jeffries, supra note 25 . If Redish's sole desire was to allocate decisionmaking authority to individuals rather than to the government, he could still accept regulation of corporate speech, since that regulation is aimed at the economic structure and does not prevent individuals from spreading and obtaining information. In contrast, granting the government a general power to prevent private individuals from obtaining information held by the government would directly violate such an allocation of authority to individuals.

77 L. Wrttgenstenn, ON Certanti 17 e (1969). 
in our moral theories and practices than is the acceptance of democracy. The obligation to obey a law, for example, must rest on some ground other than force. ${ }^{78}$ The rather strange premise that people have an obligation (at least under certain circumstances) to obey laws that they do not support is central to many of our accepted legal and political practices. Thus, the justifications that we do or should accept for imposing legal obligations provide fundamental premises for our social order. I have argued elsewhere that the justifications that we do or should accept-as indicated by our acceptance of democracy, constitutional restraints on democracy, and many of our other moral and political practicesrequire the political-legal order to respect the autonomy and equality of worth of all its members. ${ }^{79}$ Only when the collective order exhibits this type of respect can one expect individuals to accept collective practices and decisions with which they disagree. This respect, in turn, entails providing for people's interest in both collective and individual self-rule, in both democracy and limits on collective self-rule that are designed to protect self-expressive liberties as aspects of individual self-rule.

In attributing to our constitutional scheme underlying purposes that then guide our interpretation of specific constitutional provisions, we can reasonably view the Constitution as part of an attempt to establish a legitimate order. A central purpose of the Constitution is to establish a legal order that can provide a compelling reason besides fear of punishment for obeying the lawthe same problem that John Rawls tried to resolve in $A$ Theory of Justice. ${ }^{80}$ This purpose is best fulfilled by a combination of democracy and particular limits on democracy.

A skeptic could, of course, deny any aspect of this argument. One could certainly deny, for example, that the justification of obligation has anything to do with the duty of the collective to respect individual members, or that we do or should accept democracy. ${ }^{81}$ If discussion is to proceed, though, the person who makes these denials must offer alternative explanations and be willing to consider what commitments those explanations require. One can-

78 H. L. A. Hart persuasively criticized John Austin for failing to understand this point. H.L.A. HART, THE CoNCEPT of LAW 79-82 (1961). One could conclude, however, that Hart also failed to account adequately for (as opposed to recognize the importance of) the source of obligations. See R. Dworkn, TAkng Rughts Sertousty 39-43 (1977).

${ }^{79}$ Baker, supra note 52, at 413-15; Baker, Utility and Rights: Two Justifications for State Action Increasing Equality, 84 YALE L.J. 39, 51-55 (1974).

$80 \mathrm{~J}$. Rawls, A THeORY of Justice (1971).

81 See, e.g., Redish, supra note 3, at 594 n.20. 
not "assume" a single premise from which everything else can be logically deduced. Instead, one must examine how the best explanations of the commitments involved in various practices that one accepts support each other; that is, in Dworkin's words, how our practices and principles "hang together." ${ }^{22}$. Thus, varying responses, looking to these various practices, can be given to the person who denies a specific aspect of the argument. For example, not only does the acceptability of expecting people to obey the law, on which many of our legal practices depend, require that we respect individual autonomy, which in turn requires both democracy and limits of democracy, but also our acceptance of constitutional democracy is evidence that we do accept the notion that respect for individual autonomy helps justify a legal order. In choosing among competing first amendment interpretations we may properly con: sider each interpretation's contribution to justifying legal obligation as well as its consistency with various social practices (such as our acceptance of democracy and of notions of individual responsibility), its contribution to the various values we commonly associate with the first amendment, and of course, the language of the amendment itself. I have elsewhere argued that all these considerations point to a liberty theory of the first amendment. ${ }^{83}$. Certainly Redish's focus on democracy, though inadequate as a sole basis for logically deducing a first amendment theory, seems more consistent with the liberty theory's emphasis on direct self-rule than with Redish's attempt to justify protection for corporate speech that at best makes an indirect contribution to self-rule.

\section{Postscript: Regulating Institutional Strugtures Without Limiting Freedom}

In my analysis of commercial speech, I claim that in our economic order market forces dictate the content of commercial enterprises' speech by forcing the enterprises to orient their communications toward maximizing profits, and that such speech therefore is not a manifestation of individual freedom. ${ }^{84}$ Professor Redish repeats what is probably the most common criticism of this argument: that the way in which the market structure controls speech cannot be distinguished from the way various other external forces or structures control clearly protected speech. ${ }^{85}$ Redish suggests

82 R. Dworkin, supra note 78 , at 41 .

83 Baker, supra note 21.

84 Baker, supra note 12 , at $9-14$.

85 Redish, supra note 3 , at 621 . 
that the market structure's external control of commercial speech does not distinguish commercial speech from the speech of the political candidate, the newspaper or author, or the welfare or social security recipient protesting insufficient government aid. ${ }^{86} \mathrm{Al}$ though I will not repeat my earlier attempts to explain the constitutionally relevant distinctions between commercial speech and these (or similar) examples, ${ }^{87}$ the example upon which Redish primarily focuses, ${ }^{88}-m y$ earlier explicit ${ }^{89}$ analysis of the political candidate's speech-can be clarified in light of his criticisms.

I claim that the need to get elected does not control the speech of the political candidate in the same sense that the need to make a profit controls enterprise behavior. I do not claim, however, that an individual's humanitarian or noneconomic motives deserve more protection than her self-interested or economic goals. The objection to commercial speech is not based on a judgment concerning the desirability of being "motivated by profit incentives, rather than self-expression." 90 The focus is on the individual's freedom of choice, not the content of the choice. The individual's right of freedom of expression has no relevance in a situation in which the structure dictates and enforces particular

86 Id. Redish also suggests that the market does not effectively control some aspects of the commercial enterprise's speech. Id. I agree that such speech would deserve protection if neither the market nor the law required the dominance of profit considerations. See Baker, supra note 12, at 40 . But of. supra note 30 and accompanying text.

87 Redish apparently did not notice my earlier, at least implicit, consideration of all of his examples. For my discussion of protection of the newspaper and the author, see Baker, supra note 69; Baker, supra note 12, at 25-32. As for the creative advertiser, I would claim that she has a right to engage in her chosen act of expression, but not to veto economic arrangements that limit or eliminate particular professional opportunities, Baker, supra note 12 , at 33 ; compare the pianist who, $\mathrm{I}$ argue, has a right to engage in her activity but no right to demand an economic arrangement that pays her for her expressive activities, Baker, supra note 12, at 24. See Baker, supra note 52, at 397-99. With regard to the angry welfare and social security recipients, see my discussion of the worker's situation. Baker, supra note 12 , at $40 \&$ n.138. The market does not compel the worker to seek more. Furthermore, there is no complete or principled separation of the realms of production and consumption in the worker's speech and decisions: she is free to pressure the enterprise to conform to her values. In contrast, the market's structurally enforced profit orientation does control the response of the enterprise. Although both the worker and the enterprise may be "motivated" by economic self-interest, the difference from the perspective of human liberty is the structural (and legal) enforcement of the enterprise's profit orientation. Unfortunately for those who like symmetry, this theoretical argument thus would allow greater scope for labor law regulation of employer speech than of employee speech. See supra note 35 .

88 Redish, supra note 3 , at 622 .

89 Baker, supra note 21 , at 996 n.102; cf. Baker, supra note 12 , at $34-40$ (implicit analysis of same issues).

90 Redish, supra note 3, at 621 n.107. 
choices. Thus, one must examine the political and market contexts to see in each case whether the structure dictates or enforces particular choices or whether people in fact exhibit freedom from structural distates. Moreover, even if a structure dictates choices, regulation of the structurally dictated speech would improperly abridge freedom unless the structurally dictated choices could be separated in a principled manner from, and regulated without interfering with, freely made choices.

Not only does the market structure enforce a profit orientation, but our society also generally accepts as proper the dominance of this profit motivation within the bounds of the law.91 Although necessarily vague standards like the business judgment rule make legal enforcement difficult, our laws often require directors and officers of commercial enterprises to adopt this profit orientation. In contrast, our dominant assumption with respect to the political sphere is that candidates and office-holders advocate their values and world views, and that the political process ought to combine an opportunity for honest debate about values with a process for determining which view will (at least temporarily) prevail.

Of course, these distinctions would be of little relevance if the political process actually enforced a motivation to win elections that controlled the candidate's speech choices in a manner and to an extent analogous to the market's enforcement of a profit motivation that controls the enterprise's speech. The structures, however, are not analogous. Investors supply funds to a business in order to obtain an economic return, and the market enforces this orientation toward profit-maximization on all except those commercial actors who intentionally choose to consume rather than reproduce their investment. In contrast, people commonly contribute campaign funds as a means of associating themselves with candidates who have particular attributes and views, or as a means of purchasing expression of a paticular sort. Both the citizens' contributions and the candidates' expenditures are more a matter of consumption than investment. Alternatively, if (with some pressure on the term "investment") one described the contributions or expenditures as an investment, the investment would be in promoting particular views or values expressed or held by the candidate, not in achieving an economic return that is independent of the expressed values. Of course, in the political context one's views and values are usually

91 But see, e.g., Herald Co. v. Seawell, 472 F.2d 1081, -1094-96 (10th Cir. 1972) (holding that the obligations of a large metropolitan area newspaper extend to employees and the general public as well as to the shareholders). 
best advanced by prevailing electorally. Nevertheless, nothing about the political context requires that political contributions or the candidate's personal expenditures be designed only to purchase winning speech, as opposed to speech that promotes their views or values. The political process also provides for raising and using new funds in each election, thereby separating political activity from the necessity of reproducing used capital. Rather than dictating speech independently of values, the structure thus assumes and encourages a correspondence between people's values and their speech. The expenditures and contributions are value-based consumption- "investment" in specific values.

This relation between speech and values, although not universal, is socially assumed and structurally encouraged in the political sphere. Although it commonly exists within most political groups, this speech-value linkage is most overtly illustrated by numerically small but ideologically committed minorities that could not possibly prevail electorally (at least not without compromise and submergence in a broader coalition), but that nevertheless often organize minority parties or offer independent candidates as a means of publicizing and hopefully spreading the group's views. Unlike the market context that makes the economic return basic and the values expressed irrelevant, the political context thus provides an opportunity in which advocacy and the spread of particular views will often be the basic concern of both candidates and contributors. ${ }^{92}$

The critical issue is whether the political structure enforces "choices," thereby making one's personal values irrelevant. Even if one were "convinced that ninety-nine percent of candidates [and their supporters?] were actually motivated more by the desire for clection than by the desire to express their values," 93 the "logic" 94 of my argument would still mandate protection of the speech, if this goal was freely selected by the speaker. To be sure, such a degree of uniformity of motivation among people to treat their values as irrelevant to their speech would provide strong circumstantial support for the view that the structure does enforce a particular dominant, instrumentalist orientation. I do not believe, however, that there is such a high degree of uniformity in this

92 of course, winning may be the dominant or even exclusive goal for some individual politicians. See Redish, supra note 3 , at 622 ("[I]t certainly seems counter-intuitive to me . . . to think that most candidates for office do not have election as their primary goal."). This raises questions both about whether this goal is structurally mandated and about the separability of motives. See infra text accompanyinrg notes 93-98.

${ }^{93}$ Redish, supra note 3 , at 622 .

94 Id. 
matter. Because of people's desire to have their viewpoints expressed, candidates often run-and receive the support of political parties and individual contributors-even though they have no realistic hope of winning. In safe districts, this situation will often exist even in the case of one of the major party candidates; more frequently, the desire to have a viewpoint presented explains the activities of minor parties. Even when a minor party candidate has a chance of winning, the goal of the candidate and her party normally will be to win on their platform, not just to win for its own sake. Moreover, I suspect that, even for a major party candidate with a good chance of winning, this probability is often not a necessary condition for the candidate's and the contributors' decisions. Thus, although the empirical percentages are not the basis of my analysis, I think that Redish's "hard-nosed" speculations are unrealistic.

Redish also argues that my analysis of commercial speech fails because of "the inseparability of the profit motive from the desire for self-expression." 95 Nevertheless, it is precisely the possibility of separating the structurally determined aspect of conduct from the individually chosen aspect that marks a fundamental distinction between the market and the political context. The structure of elections, with its premium on winning, certainly influences, even if it does not dictate, the politician's speech. ${ }^{98}$ Nevertheless, in regulating the candidate's expression, one cannot separate this structural influence from the influence resulting from the candidate's or her contributors' values. There is no apparent way to "purify" the campaign speech by eliminating the effect of the concern with winning. In the commercial sphere the government could regulate the speech with the proviso that the regulation does not apply if the individual attributes the speech to her personal value choices, with the obvious tax consequences. This regulation, however, would not help us to categorize speech in the electoral context, because the candidate would, as she does in her speeches, always attribute the speech to her personal value commitments. Thus, protection of the candidate's or contributor's freedom of speech rules out regulation in the electoral (as well as in the broader political) context.

95 Id. 621.

96 Whereas the market's promotion of profit-maximizing behavior is typically taken to be its primary merit, the electoral process's influence on political speech is often viewed as an evil justifying attempts to reshape the incentives placed on political activity in order to encourage more thoughtful approaches to collective decisions. 
In contrast, in the commercial context, one can separate the sponsor's value choices from market dictates. Because the regulation is justified by the speech's source in the structural demands of the market, the state can only regulate or prohibit speech that the speakers themselves attribute to the market rather than to their own value choices. Thus, although the government can prohibit market-controlled speech, the speech must be permitted if the individual businessperson treats the speech as personal, for example, as an individual expenditure rather than as a business expense for income tax purposes.

Even where the classic view that the market dictates profitmaximizing choices does not apply, this ability to require that the expression be attributed either to business needs or to personal choice answers other possible arguments for protecting corporate speech. Today, liberals frequently conclude that the classic market paradigm does not describe the world of multinational corporations and oligopolistic market power. ${ }^{97}$ Although one should be cautious about accepting these arguments too readily or ignoring the extent to which the market keeps profit concerns dominant even in areas of diminished competition, even where the critique applies, democratic theory still would not justify granting corporate executives discretionary control over the massive corporate resources, which were gathered for commercial purposes, in order to pursue their personal political objectives. If the corporate management should instead claim that the discretionary speech represents the shareholders' personal values, the government could require that these shareholders individually agree to contribute to the costs of the speech, and could preclude them from deducting the cost of their contributions as a business expense. ${ }^{98}$ Thus, one does not need to know which description of the economic world best describes a given situation, because in either case, although for different reasons, the political speech attributed to the corporation would be constitutionally subject to regulation.

Thus, contrary to Redish's argument, the candidate's speech differs from commercial speech in two vital ways. First, the political context, unlike the commercial sphere, allows and even

97 C. LINDBLOM, supra note 6, at 155 . Herbert Gintis contrasts the claim that corporate management exercises discretionary control (a view that he labels "Galbraithian") with his view that the capitalist market structure itself restricts or controls the major choices. Gintis, Consumer Behavior and the Concept of Sovereignty: Explanations of Social Decay, 62 AM. Econ. Rev. (PAPErS \& Proc.) 267 (1972).

${ }^{98}$ See Baker, supra note 12 , at $37-40$. 
encourages individuals' values to control the content of the speech. Second, only the political context prevents separation of any structurally controlled content from the individually chosen content. A focus on individual liberty or self-realization would require protection of political speech financed by a candidate or a noncommercial contributor, but not of market-dictated corporate political speech. 